\title{
Effect of Fiber Mat Density and Crushing Mechanism on the Energy Absorption Capacity of GFRP Crashworthy Tubes
}

\author{
Chethana K.Y, M. G. Patil, Y. S. Rammohan
}

\begin{abstract}
The aim of this study is to examine the effect of fiber mat's density and deformation mechanism of tubes with and without die compression. In this study a new mode of deformation mechanism of density graded GFRP circular tube is examined when they are subjected to axial compression on to a die and without die to examine its energy absorbing capacity. Theoretical calculations were made to predict the crushing stress of different specimens. It is observed that increasing density of fiber increases energy absorption value but decreases the specific energy absorption and the die could trigger progressive crushing additionally decreasing peak load. Here the compressed tube wall is compelled to be deformed towards the end of compression die with a little range of bending curvature which was forced by the radius of the die at high crushing stress and the major part of the deformation takes place at a nearly constant load, which leads to high energy absorption capacity. Comparison between theoretical prediction values by derived equations and the experimental results shows good correlation.
\end{abstract}

Index Terms: GFRP, Experimentation, Energy absorption, Theoretical Calculations

\section{INTRODUCTION}

Impact load energy absorbing components are utilized where impact between two bodies is a probability and where either or the two bodies must be protected from serious damage [1].The minimum peak load and maximum specific energy absorption are the main requirements for the energy absorber. FRP tubes which absorb the energy are subjected to progressive deformation and are extremely productive in impact energy absorbing devices.

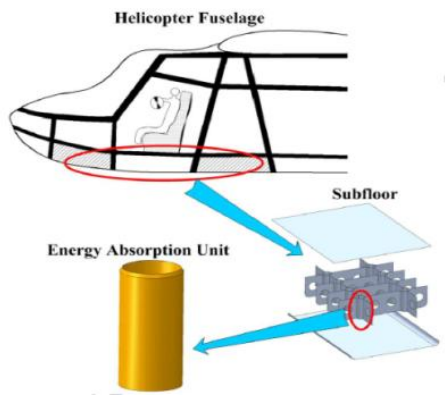

Figure 1: Crashworthy Structure in helicopter subfloor [8]

Revised Manuscript Received on July 22, 2019

Chethana K.Y, Department of Mechanical Engineering, Vemana Institute of Technology, Bangalore, India

M. G. Patil, Department of Mechanical Engineering, BMS College of Engineering, Bangalore, India

Y.S. Rammohan, Department of Mechanical Engineering BMS College of Engineering, Bangalore, India

Circular cross-section tubes are widely used as impact energy absorbing components as shown in Fig.1 the tube may be subjected to axial compression between two plates or between a plate and a special die. In this case tube has been examined by many researchers and the tube deforms by progressive crushing in petal mode.

\section{COMPRESSION DIE AND MATERIALS}

\section{A. Compression Die}

The die was formed by turning an EN8 steel rod of diameter $85 \mathrm{~mm}$ in lathe machine. These machined die are hardened in a heat treatment furnace. Brinell hardness test was then conducted on the formed die to evaluate the hardness of the material and was found to be 400 BHN for EN8 steel die. The designed die for circular cross section GFRP tubes are shown in Fig.2. Here fillet is made on the location, where one end of the FRP tube contacts with the die. Keeping in mind the end goal is to put the FRP tubes into the die serenely and steadily, the external diameter of the die is made only same as the internal diameter of the FRP tubes.

Here two different die are formed i.e. single radius die is of $7 \mathrm{~mm}$ fillet, and double radius die also $7 \mathrm{~mm}$ fillet.
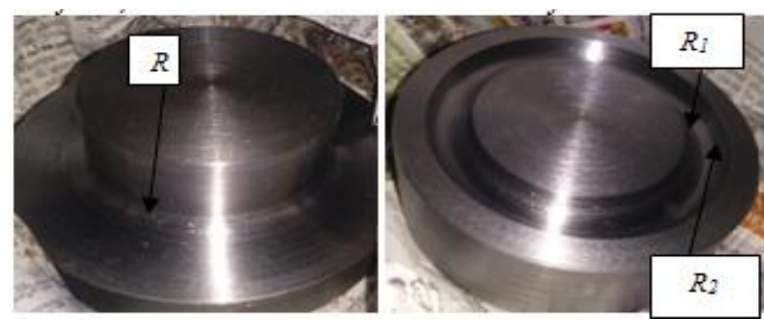

Figure 2: (a) Single radius die (b) Double radius die

B. Materials

Method: Hand layup/Hand wraps technique

Materials Used:

Matrix: Polyester Resin, Reinforcement: E -Glass fiber of different density of $300 \mathrm{gm} / \mathrm{m}^{2}$ mat, $450 \mathrm{gm} / \mathrm{m}^{2}$ mat

and $600 \mathrm{gm} / \mathrm{m}^{2}$ mat, Hardener: MEKP (Methyl Ethyl Ketone Peroxide). From the below configuration 4 different specimens are fabricated

1. Specimens are made by $300 \mathrm{gm} / \mathrm{m}^{2}$ fiber

2. Specimens are made by $450 \mathrm{gm} / \mathrm{m}^{2}$ fiber

3. Specimens are made by $600 \mathrm{gm} / \mathrm{m}^{2}$ fiber

4. Specimens are made by layer of $300 \mathrm{gm} / \mathrm{m}^{2}$ fiber, layer of $450 \mathrm{gm} / \mathrm{m}^{2}$ fiber, and layer of $600 \mathrm{gm} / \mathrm{m}^{2}$ fiber. 


\section{Planar specimens}

Planar specimens are fabricated for the purpose of finding out material properties like Young's modulus, bending stress, inter-laminar fracture toughness, intra-laminar fracture toughness and coefficient friction between specimens and die material.

\begin{tabular}{|c|}
\hline $300 \mathrm{gm} / \mathrm{m} 2$ \\
\hline $300 \mathrm{gm} / \mathrm{m} 2$ \\
\hline $300 \mathrm{gm} / \mathrm{m} 2$ \\
\hline
\end{tabular}

a)Laminate Made of Iso fibers of 300gm/m2 Fiber Mat

\begin{tabular}{|c|}
\hline $450 \mathrm{gm} / \mathrm{m} 2$ \\
$450 \mathrm{gm} / \mathrm{m} 2$ \\
$450 \mathrm{gm} / \mathrm{m} 2$ \\
\hline
\end{tabular}

b)Laminate Made of Iso fibers of $450 \mathrm{gm} / \mathrm{m} 2$ Fiber Mat

\begin{tabular}{|c|}
\hline $600 \mathrm{gm} / \mathrm{m} 2$ \\
\hline $600 \mathrm{gm} / \mathrm{m} 2$ \\
\hline $600 \mathrm{gm} / \mathrm{m} 2$ \\
\hline
\end{tabular}

c)Laminate Made of Iso fibers of $600 \mathrm{gm} / \mathrm{m} 2$ Fiber Mat

\begin{tabular}{|c|}
\hline $300 \mathrm{gm} / \mathrm{m} 2$ \\
\hline $450 \mathrm{gm} / \mathrm{m} 2$ \\
\hline $600 \mathrm{gm} / \mathrm{m} 2$ \\
\hline
\end{tabular}

d)Laminate Made of Density Graded fibers

Figure 3: The configuration of planar specimens

\section{Tubular Specimens}

Tubular specimens are fabricated by using hand wrapping technique, these specimens are fabricated to conduct axial compression test to know the energy absorbing capacity.

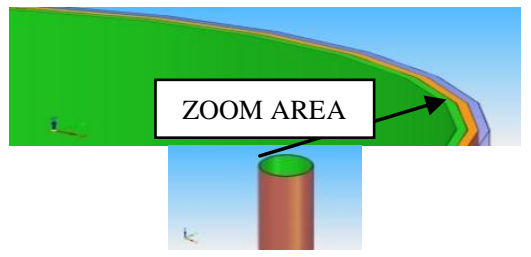

Figure 4: Schematic CAD Model tubes made by Graded mat

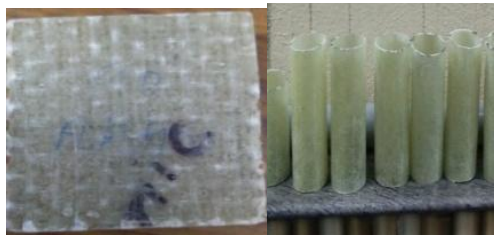

Figure 5: The Planar and tubular specimens

\section{EXPERIMENTATION}

\section{A. Testing On Planar Specimens}

ASTM D3039-76 standard specimen was used for tensile testing, ASTM D790-03 standard specimen was used for flexural testing, ASTM D5528 standard specimen was used for inter-laminar fracture testing(DCB specimen), ASTM D5045 standard specimen was used for intra-laminar fracture testing (CT specimen).The above tests were performed on the electronic UTM model TFUC-1000.ASTM G99specimens were used for wear testing by using DUCOM model TR 201 pin on disc type computerized wear testing machine. The obtained results are tabulated in Table 1 and 2 .

\section{B. Testing On Tubular Specimen (Quasi-Static} Compression Test)

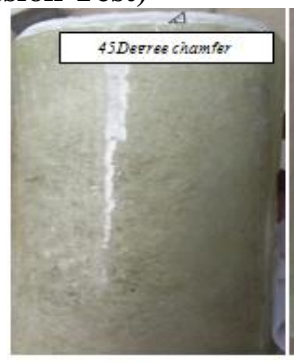

(a)

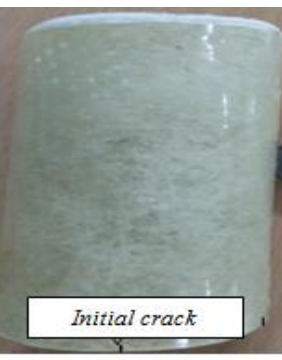

Figure 6: The prepared tubes for (a) flat platen compression (b) die compression

The tubes were machined into individual specimens with height of 2.5 times diameter. One end of the tube was chamfered with $45^{\circ}$ in order to initiate progressive crushing and minimize the initial peak load effect on the entire tube as shown in Fig.6a. Quasi-static tests were employed on displacement controlled universal testing machine (FIE make) with the maximum load cell of $250 \mathrm{kN}$. Specimens were axially crushed between parallel steel flat platens at a constant cross-head speed of $3.0 \mathrm{~mm} / \mathrm{min}$. Three repeat experiments were carried out for each kind of tube to verify the stability of energy absorption capability.

Another set of tubes were compressed on to a single radius and double radius die. In this case one end of the tube was made cuts on the wall to initiate intra-laminar cracks as shown in Fig $6 b$.

\section{Experimental methods}

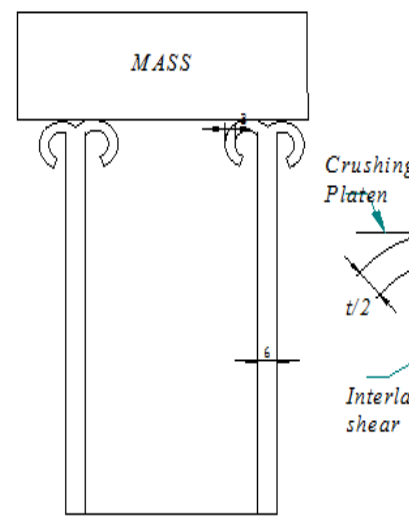




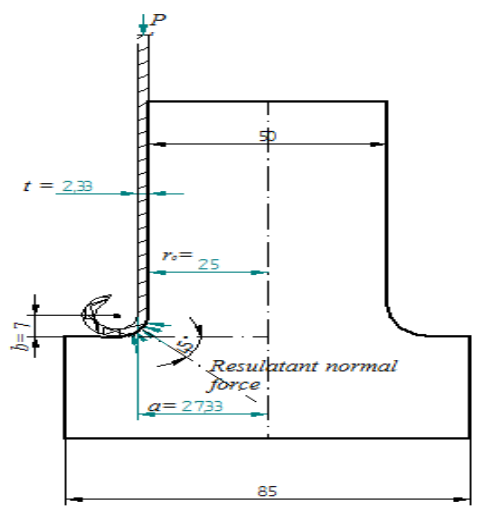

Figure 7a: The deformed mode of GFRP tube compressed by flat platens without die (a) and with $\operatorname{die}(b)$.

As the compression modes illustrated in Fig.7 a and b, the tube compressed under two flat platen deforms the tube wall by splitting into two fronds i.e. inside and outside bending, whereas tube deformed with help of die ,tubes split into single frond, thus maintaining the same thickness of the tube wall.

\section{THEORETICAL CALCULATIONS}

In this section theoretical calculations are done, considering the specimens are crushed under axial compression in two cases i.e. specimens crushed with die and without die.

\section{A. Considering tube compressed under flat platens}

During the deformation of tube by wall bending like petalling, over a radius of curvature, the magnitude of these stresses $\left(\sigma_{c}\right)$ depends on the radius of curvature and the thickness of the beam[7], as the relationship expressed by equation.

According to bending equation

Bending stress becomes

$$
\sigma=\frac{E t}{2 R}
$$

Where the E is the Young's modulus of the beam is parallel to the fibers is the thickness of the petal and $R$ is radius of curvature. This equation is further modified by considering inter-laminar energy release rate. This equation is obtained by [9]. Considering inter-laminar fracture toughness.

$$
\sigma_{\mathrm{c}}=\frac{2}{\mathrm{a} \sin \theta} \sqrt{\frac{\mathrm{GEb}}{3}}+\frac{\pi^{2} \mathrm{Eh}^{2}}{121^{2}} \sec \theta
$$

Where

$\theta=$ Crack opening angle in degree =Inter-laminar energy release rate in $\mathrm{N} / \mathrm{m}, \mathrm{h}=$ Thickness of the tube wall in $\mathrm{mm}, \mathrm{E}$ $=$ Elastic modulus in $\mathrm{N} / \mathrm{mm}^{2}, \mathrm{~L}=$ Length of the tube in $\mathrm{mm}, \mathrm{b}=$ Width of the specimen in $\mathrm{mm}$.

\section{B. Considering tube compressed under die}

The estimated load for splitting of axial compressed tubes on die[1] depends on frictional load, intra-laminar fracture toughness and number of initiated cracks[1]. as given by

$\mathrm{P}_{\mathrm{S}}=\frac{2 \pi N 0 \operatorname{ro}\left\{\ln \frac{a}{r o}+\frac{t}{4 b}\right\}+n G c t}{1-\sqrt{2 \mu^{2}} /\left(1+\mu^{2}\right)}$

Where $\mathrm{a}=$ Radial distance of crack tips from axis of the tube, $\mathrm{b}=$ radius of the tube, $\mathrm{G}_{\mathrm{c}}=$ Intra-laminar fracture toughness $\mathrm{N}_{0}=\sigma_{0} \mathrm{t}=$ Fully plastic membrane force per unit length of tube wall, $\mathrm{n}=$ Number of initiated cracks, $\mathrm{P}_{\mathrm{s}}=$ Steady state load, $\mathrm{r}_{0}=$ Radius of the tube, $\mathrm{t}=$ Thickness of the tube, $\mu=$ Coefficient of friction between tube wall and die .

The obtained estimated load is divided by cross sectional area and gives the crushing stress of the corresponding tubes.

\section{RESULTS \& DISCUSSION}

Table 1: The Longitudinal Young's modulus, bending stress and coefficient of friction

\begin{tabular}{lccc}
\hline Laminate & $\begin{array}{l}\text { Longitudinal } \mathrm{E} \\
(\mathrm{GPa})\end{array}$ & $\begin{array}{l}\text { Bendin } \\
\text { g Stress } \\
(\mathrm{MPa})\end{array}$ & $\begin{array}{l}\text { Coefficie } \\
\text { nt of } \\
\text { friction } \\
(\mu)\end{array}$ \\
\hline $\begin{array}{l}300 \\
\mathrm{gm} / \mathrm{m} 2\end{array}$ & 23.5 & 343 & 0.3129 \\
\hline $\begin{array}{l}450 \\
\mathrm{gm} / \mathrm{m} 2\end{array}$ & 24.33 & 403 & 0.3274 \\
\hline $\begin{array}{l}600 \\
\mathrm{gm} / \mathrm{m} 2\end{array}$ & 26.7 & 421 & 0.3434 \\
\hline Graded & 24.56 & 408 & 0.3918 \\
\hline
\end{tabular}

Table.1 shows the longitudinal elastic modulus, bending stress and coefficient of friction obtained by experimentation on planar specimens.

Table 2: Inter-laminar and intra-laminar fracture toughness

\begin{tabular}{lcc}
\hline $\begin{array}{l}\text { Lamina } \\
\text { te }\end{array}$ & $\begin{array}{l}\text { Inter-laminar Fracture } \\
\text { Toughness }(\mathrm{N} / \mathrm{m})\end{array}$ & $\begin{array}{l}\text { Intra-laminar Fracture } \\
\text { Toughness }(\mathrm{N} / \mathrm{m})\end{array}$ \\
\hline $\begin{array}{l}300 \\
\mathrm{gm} / \mathrm{m} 2\end{array}$ & 376.71 & 376.71 \\
\hline $\begin{array}{l}450 \\
\mathrm{gm} / \mathrm{m} 2\end{array}$ & 414.37 & 414.37 \\
\hline $\begin{array}{l}600 \\
\mathrm{gm} / \mathrm{m} 2\end{array}$ & 431.36 & 431.36 \\
\hline graded & 414.82 & 414.82 \\
\hline
\end{tabular}

Table. 2 shows the Inter-laminar and intra-laminar fracture toughness obtained by DCB and CT specimens respectively.

Table 3: comparison of Theoretical crushing stress

\begin{tabular}{ccc}
\hline $\begin{array}{c}\text { Type of } \\
\text { tube }\end{array}$ & $\begin{array}{c}\text { Without } \\
\text { die(MPa) }\end{array}$ & $\begin{array}{c}\text { With die } \\
(\mathrm{MPa})\end{array}$ \\
\hline $\begin{array}{c}300 \\
\mathrm{gm} / \mathrm{m} 2\end{array}$ & 168.443 & $\begin{array}{c}234.4511 \\
9\end{array}$ \\
\hline $\begin{array}{c}450 \\
\mathrm{gm} / \mathrm{m} 2\end{array}$ & 175.1496 & $\begin{array}{c}269.4414 \\
1\end{array}$ \\
\hline $\begin{array}{c}600 \\
\mathrm{gm} / \mathrm{m} 2\end{array}$ & 178.6726 & $\begin{array}{c}284.1099 \\
2\end{array}$ \\
\hline Graded & 175.9130 & $\begin{array}{c}260.3523 \\
125\end{array}$ \\
\hline
\end{tabular}




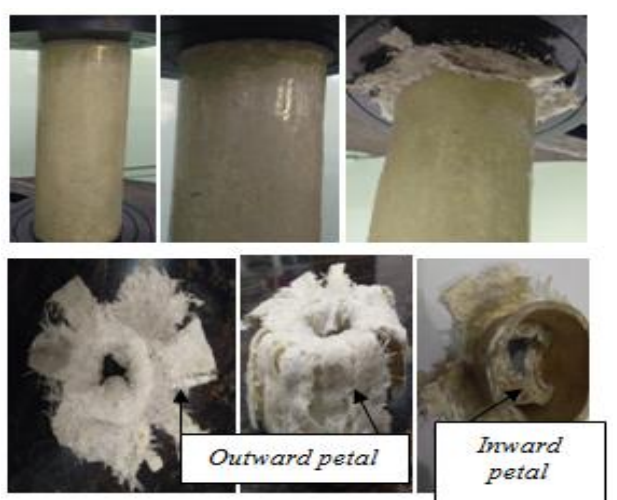

Figure 8: Deformation of tubes by flat platens without die

Theoretical crushing stresses of tubes crushed under two flat platens were calculated by equation number 2 , by considering interlaminar energy release rate. Whereas theoretical crushing stress of tube crushed by die were calculated by equation number 3 by considering intralaminar energy release rate and the calculated results tabulated in Table 3 . Representative photos taken during tube crushed by flat platens without die compression, deformed by splitting single tube wall into two halves outward and inward petalling as shown in Fig.8.

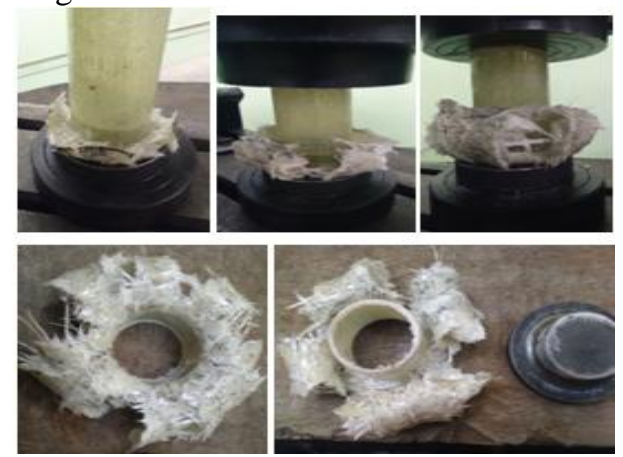

Figure 9: Deformation of tube with single radius die

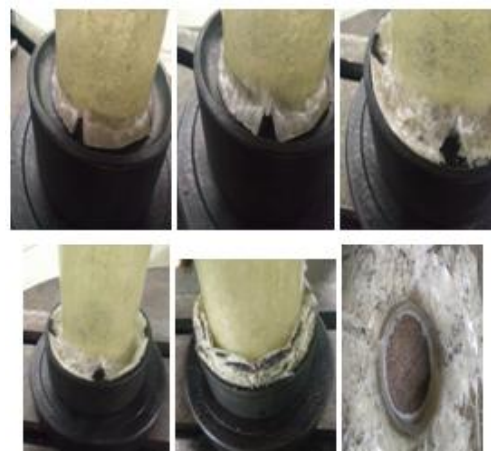

Fig.10. Deformations of tube with double radius die

Photographs taken during testing of tubes with single radius die compression deformed by bending of tube wall on to the die radius and the deformed petals were freely moving outwards, maintaining single wall thickness as shown in Fig.9. Photographs taken during testing of tube with double radius die compression deformed by bending of tube wall on to the first fillet and the deformed petals were rubbed by second fillet with friction and move upwards, maintaining single wall thickness as shown in Fig.10.

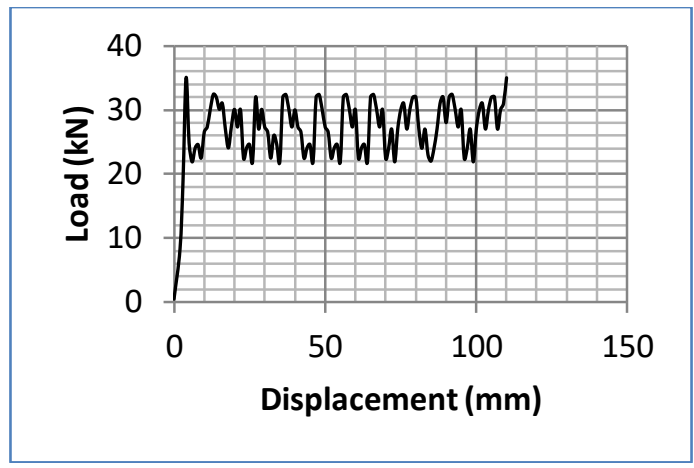

Fig.11.Load-Dispalcement graph of tube compressed by flat platens without die

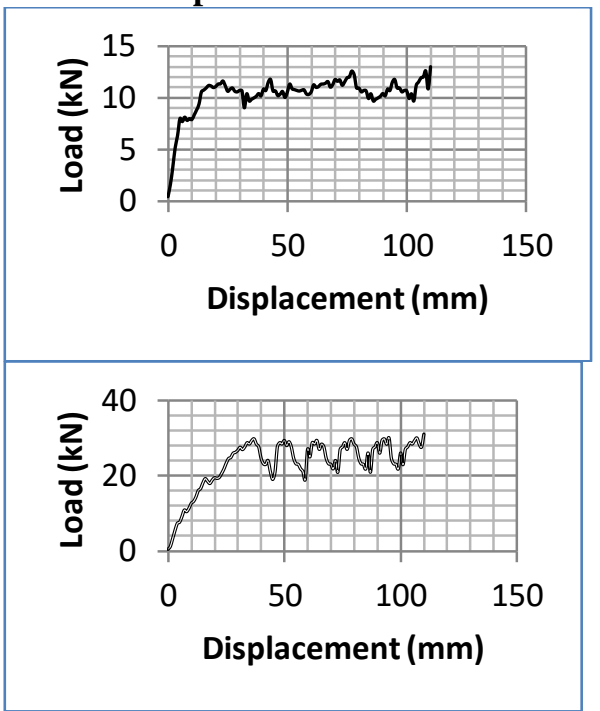

Fig.12.Load-Dispalcement graph of tube compressed with single radius die(a) and double radius die(b).

Load-displacement curves obtained by axial compression of tube crushed by flat platens as shown in Fig.11, here progressive petalling of tubes by multiple fractures like inter-laminar cracks, matrix failure and fiber failure, gives variable load displacement curve, whereas in case of tube crushed by single radius die deformed due to intra-laminar fracture of tube wall, it gives steady load curve with minimum peak load as shown in Fig.12a. The tube crushed by double radius die is due to intra-laminar tube wall failure with more friction between die and tube wall and it gives more area under the load-displacement curve with minimum peak load is as shown in Fig.12b.

Table 4: Experimental results of axial crushing of tubes

\begin{tabular}{|c|c|c|c|c|}
\hline $\begin{array}{c}\text { Type of } \\
\text { Specimen }\end{array}$ & $\begin{array}{c}\text { Peak } \\
\text { load ( } \\
\mathrm{kN})\end{array}$ & Energy (kJ) & $\begin{array}{c}\text { Mass } \\
(\mathrm{kg})\end{array}$ & $\begin{array}{l}\text { specific } \\
\text { energy ( } \\
\mathrm{kJ} / \mathrm{kg})\end{array}$ \\
\hline $\begin{array}{c}300 \mathrm{~g} / \mathrm{m}^{2} \\
\text { without } \\
\text { die }\end{array}$ & 22 & 2.447 & 0.098 & 24.717 \\
\hline $\begin{array}{c}450 \mathrm{~g} / \mathrm{m}^{2} \\
\text { without } \\
\text { die }\end{array}$ & 27 & 3.0275 & 0.10 & 30.275 \\
\hline $\begin{array}{c}600 \mathrm{~g} / \mathrm{m}^{2} \\
\text { without } \\
\text { die }\end{array}$ & 30 & 3.6075 & 0.110 & 32.79 \\
\hline $\begin{array}{l}\text { Graded } \\
\text { tube } \\
\text { without } \\
\text { die }\end{array}$ & 28 & 3.5712 & 0.106 & 33.69 \\
\hline
\end{tabular}




\begin{tabular}{|c|c|c|c|c|}
\hline $\begin{array}{c}\text { Graded } \\
\text { tube with } \\
\text { Single } \\
\text { radius die }\end{array}$ & 11.98 & 1.2584 & 0.106 & 11.871 \\
\hline $\begin{array}{c}\text { Graded } \\
\text { tube with } \\
\text { double } \\
\text { radius die }\end{array}$ & 18 & 3.6847 & 0.106 & 34.76 \\
\hline
\end{tabular}

\section{CONCLUSION}

Tubes of different density fiber mat are compressed axially. Energy absorption capacity of the tubes increases as density of the fiber mat increases but specific energy absorption capacity decreases as density of the fiber mat increases. But the tube made of all three different fiber mat (Density graded) gives better Specific energy absorption than tubes made of iso fiber mat. In the next set density graded tube compressed by single radius die gives minimum peak load with minimum specific absorption, but density graded tube compressed by double radius die gives better energy absorption with minimum peak load than all other tubes.

\section{REFERENCES}

1. T.Y.Reddy and S.R. Reid, Axial splitting of circular metal tubes, International Journal of Mechanical Sciences, 28 (2)( 1986)

2. S.R.Reid, Plastic deformation mechanisms in axially compressed metal tubes used as impact energy absorbers, International Journal of Mechanical Sciences 35 (12) ( 1993)

3. A.G.Mamalis, D.E.Manolakos, Demosthenous and M.B. Ioannidis,Experimental determination of splitting in axially collapsed thick-walled fibre-reinforced composite frusta, Thin-Walled Structure 28 (3)(1997).

4. G.L.Farley,Energy absorption of composite materials, Journal of Composite Materials 17 (3) (1983).

5. Thornton P.H.,Energy absorption in composite structures, Journal of Composite Materials 13(3) (1979).

6. A.G.Mamalis,M.Robinson,D.E.Manolakos,G.A.Demosthenous,M.B.I oannidis\&.Carruthersb,Crashworthy capability of composite material structures, Composite Structures 37(3)( 1997).

7. D. Hull, A Unified Approach to Progressive Crushing of Fibre-Reinforced Composite Tubes, Composites Science and Technology 40 (4)(1991).

8. Wang, Y., Feng J., Wu J., Hu D., Effects of fiber orientation and wall thickness on energy absorption characteristics of carbon-reinforced composite tubes under different loading conditions, Composite Structures 153(1)(2016)

9. Ang soon Lim, Predicting the crushing stress of composite materials, A dissertation, university of southern Queensland, Nov 2006.

10. M.S. Sham Prasad, C.S. Venkatesha, T. Jayaraju, Experimental Methods of Determining Fracture Toughness of Fiber Reinforced Polymer Composites under Various Loading Conditions, Journal of Minerals \& Materials Characterization \& Engineering 10 (13)( 2011).

11. Chiu LNS, et al. Crush responses of composite cylinder under quasi-static and dynamic loading. Composite Structures 131(4) 2015.

12. Alkbir MFM, Sapuan SM, Nuraini AA, Ishak MR. Effect of geometry on crashworthiness parameters of natural kenaf fibre reinforced composite hexagonal tubes. Material Design 60(12) (2014).

13. Sebaey, T.A. and Mahdi, E. Filler Strengthening of Foam-Filled Energy Absorption Devices Using CFRP Beams, Composite Structures 160 (1) (2017).

\section{AUTHORS PROFILE}

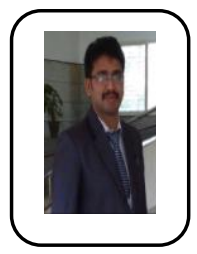

Chethana K.Y. Research Scholar at BMSCE, Assistant Professor at VEMANA IT, BE (Mechanical Engineering),M.Tech (Machine Design),PhD Pursuing (Materials), 16 Papers published in International Journals.

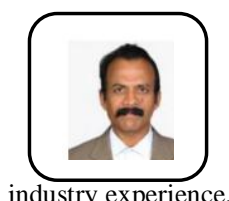

Dr. M. G. Patil, Associate Professor, Dept. of Mechanical Engineering, BMS College of Engineering Bengaluru, BE (Mechanical Engineering),M.Tech (Machine Design),PhD in Materials (IIT Roorkela),13 years of teaching experience, 3 years of research, 1 year industry experience..

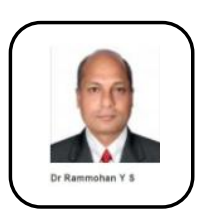

Dr. Y. S Rammohan, Associate Professor, Dept. of Mechanical Engineering, BMS College of Engineering Bengaluru, BE (Mechanical Engineering),M.Tech (Machine Design), $\mathrm{PhD}$ in Aero Structures (IIT,Madras), 16 years of teaching experience, 3 years of research , 1 year industry experience, ISTE and FPSI memberships. 